\title{
COMUNICADOS
}

\section{Leaf spots on Codiaeum variegatum caused by Colletotrichum gloeosporioides}

\author{
Beatriz Meireles Barguil ${ }^{1}$, José Evando Aguiar Beserra Júnior ${ }^{2}$, Sônia Maria Alves de Oliveira ${ }^{1}$
}

\begin{abstract}
${ }^{1}$ Departamento de Agronomia, Universidade Federal Rural de Pernambuco, CEP 52071-900, Recife-PE, Brasil, e-mail: biabar@ yahoo.com.br; ${ }^{2}$ Departamento de Fitopatologia, Universidade Federal de Viçosa, CEP 36570-000, Viçosa-MG, Brasil.

Autor para correspondência: Beatriz Meireles Barguil. e-mail: biabar@yahoo.com.br

Data de chegada: 18/12/2006. Aceito para publicação em: 28/11/2007
\end{abstract}

1437

A member of the family Euphorbiaceae, Codiaeum variegatum is a species of Indian and Malaysian origin and popularly referred to as "folha imperial" in Brazil. It is a woody bush, 2 to $3 \mathrm{~m}$ tall, with broad leaves of various forms and colors. These characteristics make it highly useful in landscape projects (Lorenzi, H.; Souza, H.M. Plantas ornamentais no Brasil. Nova Odessa: Instituto Plantarum. 2001. 1088p.). In February, 2006, lesions (spots) were found on leaves of C. variegatum plants located in Viçosa, Minas Gerais State, Brazil (Figure 1A). The spots were circular, with well-defined edges, gray at the center, surrounded by a concentric dark reddish-brown ring, with approximately $0.8 \mathrm{~cm}$ in diameter, where acervuli could be observed on the center of the lesion. The lesions evolved into necrotic tissues, which eventually may be detached. A highly pigmented region was observed around the lesions with a reddish-brown color, suggesting a plant defense response (Figure 1B). The causal agent of the disease was isolated and cultured on potato dextrose agar (PDA). Following its development, microscopic preparations were made. Conidial dimensions were $10-25 \times 2.5-3.7 \mu \mathrm{m}$ and appressorium dimensions were $7.5-15 \times 5-8.7 \mu \mathrm{m}$. In accordance with standards of morphological characterization in the literature, the fungus was identified as Colletotrichum gloeosporioides (Sutton, B.C. The Coelomycetes. Kew: Commonwealth Mycological Institute. 1980. 696p.). A polymerase chain reaction (PCR) was carried out using oligonucleotide primers specific to the ITS region of $C$. gloeosporioides. Extraction of genomic DNA and PCR conditions were conduced as described by Freeman et al. (Freeman, S.; Minz, D.; Maymon, M.; Zveibil, A. Genetic diversity within Colletotrichum acutatum sensu Simmonds. Phytopathology, Saint Paul, v. 91, p. 586-592, 2001). A band of approximately $450 \mathrm{bp}$ in size was generated, which confirmed the morphological results (Figure 1C). Pathogenicity test was carried out by placing a PDA plug containing the structures of the fungal mycelium on needle-wounded leaves. Inoculated leaves were incubated in a humidity chamber for 48 hours. Ten days later, typical symptoms of the disease were observed. The pathogen was later isolated in PDA in accordance with the Koch`s postulates, which confirmed that $C$. gloeosporioides is the causal agent of the disease. The teleomorph, Glomerella cingulata, has been recorded as causing leaf blotch on this

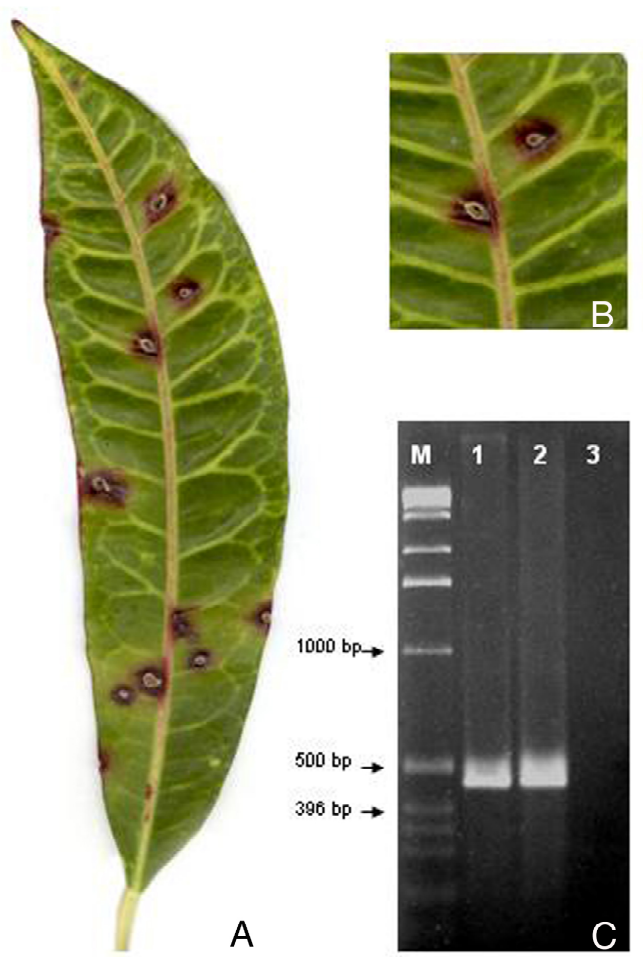

Figure 1. Leaf spots caused by Colletotrichum gloeosporioides on Codiaeum variegatum (A); pigments surrounding the leaf spot (B); electrophoresis of PCR products on agarose gel (C).

host in Great Britain (Humphreys-Jones, D.R.; Flett, S.F. Leaf blotch (Glomerella cingulata (Stonem.) Spauld. \& Schrenk) of Codiaeum variegatum (L.) Juss. Plant Pathology, London, v. 25, p. 208, 1976). Although this pathogen is ubiquitous, especially in tropical regions, it shows a very broad host range and is regularly recorded on ornamental foliage plants, this is the first description of this fungus infecting $C$. variegatum in Brazil. 